\title{
チャノコカクモンハマキ卵塊の簡易冷蔵
}

\author{
農林省茶業試験場 刈屋明
}

\section{Simplified Cold Storage of the Egg Masses of the Smaller Tea Tortrix, Adoxophyes sp.}

\author{
By Akira KARIYA
}

\author{
National Research Institute of Tea
}

\section{1 はしがき}

茶害虫にかぎらず，害虫の試験研究において，供試屁 虫を大量かつ必桨な㬨に入手することは重要な条湖であ る。そのため各框の昆虫，ダ二類について飼育与法が荐 案され利用されている。

茶管虫に拈いては，カンザワハダ二はダイズ，インゲ ン等の奻植物を用いて室内飼南されてきたが，鳞媩目韭 虫では，玉木により簡易人工飼料が開発されたことによ って, チャノコカクモン八マキAdoxophes sp., チャ マキHomona magnanima Diakonoff $の 大$ 量人工飼育 が可能になった。この人工飼料によって，数多くのコカ クモンハマキ性フェロモンの研究が奏施され，今日に至 っていることは良く知られたところである。

チャノコカクモンハマキを人工飼料によって大量に飼 育することは比較的容易であるが，試験研究の目的によ っては，少量を継籶的に必要とする埸合がある。その目 的に合5上5に飼䏍の体制を作ることは可能だが，大量 飼育を目的とする埸合とは異った困難な面が生ずる。

そこで筆者は，産即された卵塊を泠蔵して艘化期を延 長することにより，比較的簡単に各生育ステージのチャ ノコカクモンハマキを入手することを検討したので，結 果をここに報告する。

\section{2 試 験 方 法}

玉木の人工飼料により室内で飼龍しているチャノコカ クモンハマキを用いた。

透明なプラスチック容器 $(17 \times 23 \times 8 \mathrm{~cm})$ の中に, 3 客庶栫水溶液を十分含ませた脱脂綿を，底面の約 $1 / 4$ を覆 5よ5に薄く敷いて産畉箱とした。産卵箱中にチャノコ カクモンハマキの蛹（雄18頙，此15頭）を入れ，上面を 透明なポリエチレンフィルムで覆った。それ等の蛹は羽 化後交尾し，䧳成虫は上面のポリエチレンフィルムK産 卵するので，㱟日ポリエチレンフィルムを交換し，産下
された卵塊を切取った。その卵塊はらたをしないシャー レに水を含ませた沪紙を敷いてその上に並べ，硝酸カリ 飽和水溶液を底に入れたデシケータ一中に入れて， $25^{\circ} \mathrm{C}$ の恒温室で経過させた。

産畉後の経過日数について， 0 (24時間以内)， $1 ， 2$ ， 3，4，5 日關の区を設定し，それぞれについて下記の冷

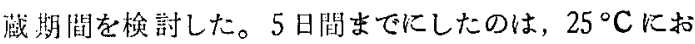
ける则期闍は約 7 日で，6日目には肧于が発䏍して頭部 がすでに見える状態になるからである。

所定の日数を経過した期塊は，シャーレのまま汇紙が 乾喿している場合は水を㭪給して，プラスチック製密閉 容器に移し泠蔵庫に入れた。冷蔵日数は，5，10，15， 20，25日間の 5 種類とした。冷蔵軍は家庭用電気椧蔵簐 (容量 $120 l$ ) で, 温度は $5 \pm 1.5^{\circ} \mathrm{C}$ であった。

所定の日数泠蔵した卵塊は，取出して再び前記の恒温 窒中のデシケーターに移して保存し，浑化状況を調査し た。供試畉塊数は1処理当り 15 畉媿である。

\section{3 結果亡考察}

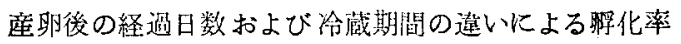
の変化は，表1のとおりである。なお，この表の毲化率

表 1 チャノコカクモンハマキ卯塊冷蔵後 の睬化率

\begin{tabular}{|c|c|c|c|c|c|c|}
\hline \multirow{2}{*}{$\begin{array}{l}\text { 産卵後の } \\
\text { 経過日数 }\end{array}$} & \multicolumn{2}{|c|}{ 冾 } & \multicolumn{2}{|l|}{ 斌 } & \multicolumn{2}{|c|}{ 数 } \\
\hline & 0 日 & 5 日 & 10日 & 15日 & 20 日 & 25 日 \\
\hline 0日 & $\%$ & $\begin{array}{r}\% \\
75.0\end{array}$ & $\begin{array}{r}\% \\
91.7\end{array}$ & $\begin{array}{r}\% \\
50.0\end{array}$ & $\begin{array}{r}\% \% \\
9.1\end{array}$ & 90 \\
\hline 1 & & 91.7 & 71.8 & 48.1 & 0 & 0 \\
\hline 2 & & 90.9 & 54.6 & 63.6 & 0 & 0 \\
\hline 3 & & 87.3 & 33.5 & 26.5 & 0 & 0 \\
\hline 4 & & 85.7 & 16.7 & 16.7 & 0 & 0 \\
\hline 5 & & 80.0 & 10.0 & 0 & 0 & 0 \\
\hline 無 処 理 & 95.0 & & & . & & \\
\hline
\end{tabular}





をるって計算した值である。

5 日間冷蔵：座瞅後の経過日数が長くなるとやや脬化 率が低下したが，産卵後 5 日間経過した卵塊でも $80 \%$ 睟 化し，冷蔵可能であった。座卵後 24 時間以内の卵塊の睬 化率が低くなっており，これは胚子の発育の段階で低温 に対する感受性に差があることによるとも考克られる が，全体の傾向からみて実験誤差と判断して差しつか光 ないであるう。

10 日間冷蔵：産畉後の経過日数が長くなるにつれて著 しく脬化率が低下した。罘子の発育が進むにつれて低温 に対する抵抗力が低下したためと考兄られる。産率後 2 日までの畉塊ならば50\%以上瞬化しているので，それを 予想して準備すれば利用可能であろう。

15 日間冷蔵：10日間冷蔵の埸合より睬化率が低下し た。特红産卵後 0 日，1日経過した卵塊で低下が著しか った。しかし，10日間冷蔵区と同じく産䀧後 2 日までの 卵塊ならば利用可能と考えられる。

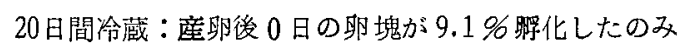
であった。産卵後 1 〜日の眆塊炕す不完全な脬化はみ られ，4 日の卵塊です睬化直前まで肧子が発肓してい た゚。産䛇後 5 日の莭塊では玲蔵期間中に不完全ながら䐻 化した卵塊があった。

25日閏冷蔵：産衤後 $0 \sim 3$ 日の卵塊で睬化したものは なかった。4〜 5 日の卵塊については, 卵内に幼虫の頭 部が黒く観察されたが归化はしなかった。5日の畉塊で は，20日䦎冷蔵区と同じく冷蔵期間に餒化したものがみ られた。

なお，15日以上冷蔵した区では，卵塊にカビが生えて そのために睬化しなかったものがあった。適当な殺菌剂 があれば睬化率が若干向上すると思われた。

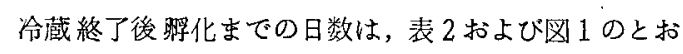
りである。この場合は不完全な睬化も含めてある。冷蔵 後の日数と冷藏前の日数を加亲るとほ深焎処理区の卵期 間と同じになった。しかし，冷蔵した場合，僅かながら 短縮して拈り，産卵後の経過日数が短い程その傾问が強

表 2 冷战終了徯睬化までの日数

\begin{tabular}{|c|c|c|}
\hline 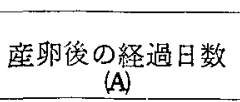 & $\begin{array}{l}\text { 冷蔵終了後娐* } \\
\text { 化まの数 } \\
\text { (B) }\end{array}$ & $(A)+$ (B) \\
\hline 0日 & 5. & 5.7 \\
\hline 1 & 5.0 & 6.0 \\
\hline 2 & 4.3 & 6.3 \\
\hline 3 & 3.5 & 6.5 \\
\hline . & 2.3 & 6.3 \\
\hline 5 & 1.6 & 6.6 \\
\hline 抵処理（畉期間） & & 7.0 \\
\hline
\end{tabular}

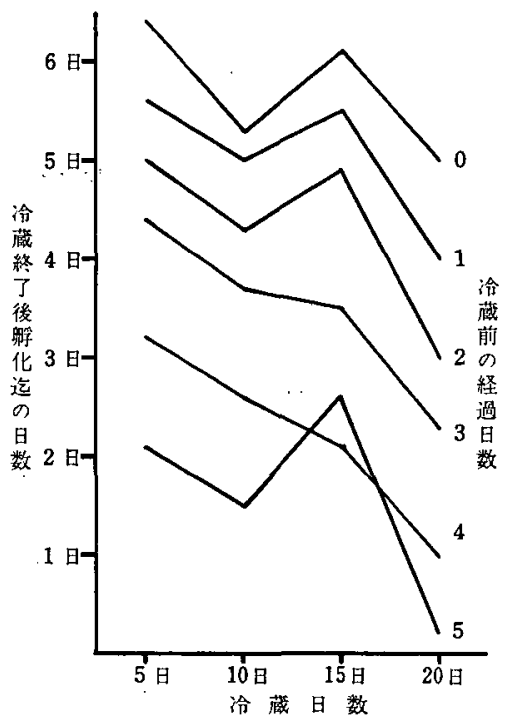

因 1 冷蔵終了後瞹化までの日数

かった。これが一般的な現象であるのか，またどのよう な原因によるのかは更に検討しなければならない。

本試験での泠蔵温度は $5^{\circ} \mathrm{C}$ 前後であったが，この温度 は発育零点索上回っているようで，冷蔵期間中にも肧子 発育が進行した。図1に示したよ5に, 産甽後経過白数 を変光たいつれれのにおいても，グラフは右下り，つま り冷蔵日数が長い程, 冷蔵終了後桴化までの日数が短く なっていた。発育雾点もしくはそれ以下の温䓘で冷蔵し た場合，冷蔵期間が延長するかどうかは興味ある問題で ある。

以上の結果，睬化率からみると，5日程度の冷蔵なら ば産卵後 5 日までのどの段階の莭塊でもよく，10〜15日


率低下を予想すればよく，20日以上の冷蔵は困難である と考えられた。

室内で累代飼育を続ける場合に，月２回産卵期がある ように，つまり 2 組の系統を維持することは比較的容易 である。この2組をもとにして，本試䍄での結果からみ で,15日間の卵塊冷蔵を組み合せれば，活添常時必要々 する材料の入手が可能である。

なお，冷蔵後の眆塊から睁化した幼虫，成虫の特性， つまり薬剤感受性, 生存能力, 繁殖力その他の変化につ いては，さらに詳細な検討が必要である。著者が性フェ ロモン利用の一環として，雌成虫フェロモンの誘引力を 検討する目的で，この方法を用いて得心雌成虫を使用し た (未発表) 筙囲では, 誘引力の变化はみられなかった が，他の目的に利用する場合は事前にチェックする必要 があるう。

* 冷蔵期間 $0 \sim 20$ 日の平均日数。 


\section{4 要約}

チャノコカクモン八マキ䛇塊の簡易冷蔵による㖥化率 の変化を検討した。

家庭用冷藏庫 $\left(5 \pm 1.5^{\circ} \mathrm{C}\right)$ 飞冷蔵した場合，5 日間

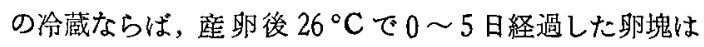

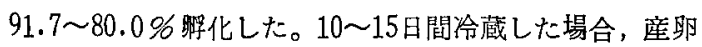
後 0 ２ 日までの䀦塊は91.7〜 50.0\%が瞹化した。20日 間以上の冷藍は团難であった。
以上の結果から，2組の累代飼育の系統を維持し，そ れに15日䦭の卵塊の簡易冷蔵を組合わせれば，活汪常特 必要とする供試材料が入手できると考光られた。

\section{5 引用文献}

1) Тамакi, I. : Appl. Ent. Zool., 1, 120 124 (1966).

(Dec. 22, 1977) 